\title{
Nienaruszalność unijnego systemu wartości jako żywotny interes Unii Europejskiej - krytyczna analiza mechanizmu egzekucji postanowień art. 2 Traktatu o Unii Europejskiej
}

\section{Streszczenie}

W żywotnym interesie Unii Europejskiej leży utrzymanie nienaruszalności jej wartości. Katalog tych wartości przedstawiono w art. 2 Traktatu o Unii Europejskiej. Mechanizm ich egzekwowania został opisany w art. 7 TUE. Warunki uruchomienia oraz obawy co do konsekwencji użycia art. 7 czynią go swoistą opcją nuklearną. Charakter art. 7 wymusił stworzenie instrumentu, który może zostać zastosowany w praktyce. W odpowiedzi na tę konieczność Komisja Europejska przyjęła w 2014 r. Nowe ramy na rzecz umocnienia praworządności. W reakcji na przedłużający się kryzys konstytucyjny w Polsce Komisja Europejska po raz pierwszy sięgnęła po stworzony przez siebie instrument, który ma na celu sprawdzenie stanu praworządności w jednym z państw członkowskich UE.

Celem opracowania jest krytyczna analiza mechanizmu opisanego w art. 7 oraz narzędzia stworzonego przez Komisję Europejską.

Przeprowadzona analiza potwierdza niską skuteczność instrumentów egzekwowania poszanowania unijnych wartości, co ogranicza możliwość adekwatnej reakcji w wypadku ich naruszenia, a przez to również efektywnego zabezpieczenia żywotnego interesu UE.

Rafał Prostak, Uniwersytet Ekonomiczny w Krakowie, Wydział Ekonomii i Stosunków Międzynarodowych, Katedra Europejskiej Integracji Gospodarczej, ul. Rakowicka 27, 31-510 Kraków, e-mail: prostakr@uek.krakow.pl 
Słowa kluczowe: wartości Unii Europejskiej, art. 7 TUE, ramy na rzecz praworządności, J.W. Müller.

Klasyfikacja JEL: K33.

\section{Wprowadzenie}

W integracji europejskiej w obrębie Unii Europejskiej zakłada się zbieżność interesów państw w niej uczestniczących oraz podzielanych wartości - od tego zależy kondycja UE oraz perspektywy jej rozwoju. Interesy narodowe państw członkowskich nie mogą zostać ujednolicone, przez co instytucje unijne są areną nieuchronnego i nieustannego ścierania się różnorodnych partykularyzmów narodowych - potrzeb, interesów i racji. Uznanie i zaspokojenie ich wszystkich jest niemożliwe.

Osiągnięcie harmonii interesów przez państwa członkowskie jest niemożliwe, trwanie i postęp integracji europejskiej są więc warunkowane potwierdzeniem wspólnoty wartości, na których oparto polityczny projekt UE i które są jednocześnie fundamentem porządków konstytucyjnych uczestniczących w nim państw. Rozbieżne interesy powodują powstawanie dystansu między państwami członkowskimi - jest to nieuniknione. Wspólne wartości mają ten dystans skracać. Owe fundamentalne wartości zostały wyartykułowane w preambule oraz $\mathrm{w}$ art. 2 Traktatu o Unii Europejskiej (TUE). W tekście preambuły potwierdzono wspólną dla państw członkowskich inspirację „kulturowym, religijnym i humanistycznym dziedzictwem Europy, z którego wynikają powszechne wartości, stanowiące nienaruszalne i niezbywalne prawa człowieka, jak również wolność, demokracja, równość oraz państwo prawne”, a także „przywiązanie do zasad wolności, demokracji, poszanowania praw człowieka i podstawowych wolności oraz państwa prawnego”. W art. 2 TUE można z kolei przeczytać: „Unia opiera się na wartościach poszanowania godności osoby ludzkiej, wolności, demokracji, równości, państwa prawnego, jak również poszanowania praw człowieka, w tym praw osób należących do mniejszości. Wartości te są wspólne Państwom Członkowskim w społeczeństwie opartym na pluralizmie, niedyskryminacji, tolerancji, sprawiedliwości, solidarności oraz na równości kobiet i mężczyzn”. Sformułowanie ustrojowej aksjologii UE oraz jej państw członkowskich otwiera traktatowy opis struktur unijnych, co potwierdza jej wagę dla istnienia i rozwoju integracji europejskiej w ramach UE.

W tekście preambuły do TUE niezbywalne prawa człowieka, godność osobowa, wolność, demokracja, równość oraz państwo prawa są określane jako powszechne wartości, a jednocześnie jako pierwsze (konstytutywne) zasady ustrojowe właściwe dla państw tworzących Unię. Podzielanie wspólnych wartości i solidarna realizacja pierwszych zasad ustrojowych przez państwa członkowskie 
ma być wyrazem wzajemnego zaufania, warunkującego kontynuację współpracy w ramach UE.

Położenie w prawie pierwotnym UE tak silnego akcentu na nienaruszalność zasad demokratycznego państwa prawa na obszarze działania Unii, w tym w granicach jej państw członkowskich, których to wspólnym dziedzictwem zasady te pozostają, oraz nakaz ich promowania w otoczeniu zewnętrznym Unii oznacza, że przestrzeganie ich leży nie tylko w jej strategicznym, ale i w ogólnym interesie, czyli że są przedmiotem żywotnego interesu Unii, a ich zabezpieczenie jest unijną racją stanu (raison d'état), a nawet racją bytu (raison d'être) ${ }^{1}$.

Historia Wspólnot Europejskich i UE jest opisem kolejnych kryzysów, które jednak nie doprowadziły do przerwania tego niepowtarzalnego w skali świata procesu integracji gospodarczej, politycznej i społecznej. Obecnie UE stoi wobec wielu wyzwań, jakimi są: niedające się przewidzieć konsekwencje decyzji o opuszczeniu struktur unijnych przez Wielką Brytanię, masowy, niekontrolowany napływ uchodźców politycznych oraz imigrantów ekonomicznych, jak również pełzający kryzys strefy euro. Skala tych trudności zmusza do wyjątkowej ostrożności w prognozowaniu przyszłości Unii. Dynamika procesów zachodzących w otoczeniu UE oraz ich odmienna recepcja przez krajowych decydentów politycznych potęguje niepewność co do możliwości wypracowania wspólnych rozwiązań. Państwa tworzące UE znalazły się na wyjątkowo niebezpiecznym kursie kolizyjnym. Nie powinno więc zaskakiwać przywoływanie przez liderów unijnej polityki fundamentalnych wartości, których przestrzeganie ma pozwolić przetrwać projektowi integracji europejskiej. Im konflikt interesów jest większy, tym ważniejsze staje się potwierdzenie oddania wspólnym wartościom.

W odpowiedzi na przedłużający i pogłębiający się w Polsce kryzys polityczny dotyczący Trybunału Konstytucyjnego Komisja Europejska podjęła decyzję o wprowadzeniu Ram na rzecz praworządności, stwierdzając istnienie systemowych zagrożeń praworządności w Rzeczypospolitej Polskiej i przekazując polskim władzom zalecenia podjęcia właściwych działań [Zalecenie... 2016]. To bezprecedensowe zdarzenie należy analizować w kontekście przewidzianego w prawie traktatowym egzekwowania przestrzegania pierwszych zasad ustrojowych - jest ono wezwaniem do poszanowania powszechnych wartości. Choć polskie władze sugerują, że Unia powinna się zająć efektywnym rozwiązywaniem problemów europejskich, nie zaś wewnętrznym kryzysem politycznym w Polsce, to wezwanie to jest konsekwentnie odrzucane jako niespójne z założeniami projektu europejskiego. Gdy spojrzy się na UE jak na wspólnotę zasad (wartości) państw o odmiennych interesach, to ochrona jedności w zakresie pierwszych zasad ustrojowych (powszechnych wartości) okaże się egzystencjalną potrzebą tej orga-

${ }^{1}$ O wartościach unijnych w kontekście zasadności istnienia UE zob. [Búrca de 2013, s. 21-37]. 
nizacji, jej żywotnym interesem. Czy można jednak ustalić wspólne rozumienie elementów składowych unijnej aksjologii? Czy UE dysponuje instrumentem rzeczywiście bezstronnej oceny naruszenia przez państwo członkowskie unijnych pierwszych zasad ustrojowych? W konsekwencji, czy aktualnie funkcjonujący system egzekwowania poszanowania unijnych wartości jest efektywny? Znalezienie odpowiedzi na te pytania wyznacza cel niniejszego artykułu. Prezentując mechanizm egzekwowania unijnych wartości, wykorzystano jego opis traktatowy oraz przybliżono specyfikę Ram na rzecz praworządności opracowanych przez Komisję Europejską. Oceny efektywności przyjętych rozwiązań dokonano na podstawie analizy krytycznej ustaleń J.W. Müllera [2013a, 2013b, 2014].

\section{Art. 7 Traktatu o Unii Europejskiej jako mechanizm egzekucji unijnych wartości}

Jeśli nienaruszalność unijnych wspólnych wartości i pierwszych zasad leży w żywotnym interesie Unii, to należało wypracować mechanizm egzekwowania przestrzegania ich przez państwa członkowskie. Wprowadzenie odpowiednich procedur nastąpiło stosunkowo późno i odbywało się dwuetapowo: najpierw określono mechanizm naprawczy (traktat z Amsterdamu z 1997 r.), a następnie mechanizm prewencyjny (traktat z Nicei z 2001 r.) [Bugarič 2014, s. 14]. Opisano je w art. 7 TUE, którego aktualna postać przedstawia się następująco:

1. Na uzasadniony wniosek jednej trzeciej Państw Członkowskich, Parlamentu Europejskiego lub Komisji Europejskiej, Rada, stanowiąc większością czterech piątych swych członków po uzyskaniu zgody Parlamentu Europejskiego, może stwierdzić istnienie wyraźnego ryzyka poważnego naruszenia przez Państwo Członkowskie wartości, o których mowa w artykule 2 . Przed dokonaniem takiego stwierdzenia Rada wysłuchuje dane Państwo Członkowskie i, stanowiąc zgodnie z tą samą procedurą, może skierować do niego zalecenia.

Rada regularnie bada, czy powody dokonania takiego stwierdzenia pozostają aktualne.

2. Rada Europejska, stanowiąc jednomyślnie na wniosek jednej trzeciej Państw Członkowskich lub Komisji Europejskiej i po uzyskaniu zgody Parlamentu Europejskiego, może stwierdzić, po wezwaniu Państwa Członkowskiego do przedstawienia swoich uwag, poważne i stałe naruszenie przez to Państwo Członkowskie wartości, o których mowa w artykule 2 .

3. Po dokonaniu stwierdzenia na mocy ustępu 2, Rada, stanowiąc większością kwalifikowaną, może zdecydować o zawieszeniu niektórych praw wynikających ze stosowania Traktatów dla tego Państwa Członkowskiego, łącznie z prawem do głosowania przedstawiciela rządu tego Państwa Członkowskiego w Radzie. Rada uwzględnia przy tym możliwe skutki takiego zawieszenia dla praw i obowiązków osób fizycznych i prawnych. 
Uruchomienie mechanizmu naprawczego (ust. 3) nie jest formalnie uzależnione od uprzedniego zastosowania mechanizmu prewencyjnego (ust. 1). Dodatkowo należy podkreślić, że ustalenia zawarte w art. 7 TUE umożliwiają organom UE podjęcie działań w sferze autonomicznej aktywności państw członkowskich, poza obszarem wyznaczonym przez prawo ustanowione przez unijnego normodawcę, prezentacja unijnych wartości jest zaś bardzo ogólna. W komunikacie Komisji Europejskiej z 2003 r. potwierdzono, że ogólność opisu unijnych pierwszych zasad, wykraczających poza zakres unijnego prawodawstwa, było intencjonalne i uzasadnione [Komunikat Komisji do Rady... 2003, s. 5]:

Zakres art. 7 nie jest ograniczony do sfer objętych prawem unijnym. Oznacza to, że Unia może reagować nie tylko wtedy, gdy naruszane są wspólne wartości w tej ograniczonej przestrzeni (acquis communautaire - przyp. R.P.), lecz również wtedy, gdy mamy do czynienia z naruszeniami w obszarze autonomicznych działań państw członkowskich. Fakt, że art. 7 unijnego Traktatu ma horyzontalny i ogólny charakter jest zupełnie zrozumiałe, jako że jest to artykuł poszukujący zabezpieczenia uznania warunków członkowstwa w Unii Europejskiej. Byłoby paradoksem ograniczenie możliwości reagowania Unii do sfer objętych unijnym prawem i ignorowanie poważnych naruszeń $w$ sferach narodowej jurysdykcji. Gdy państwo członkowskie dopuszcza się naruszeń fundamentalnych wartości w sposób wystarczająco poważny, by uruchomić art. 7, prawdopodobnie podważa ono wartości Unii i zaufanie wzajemne jej członków, bez względu na to, w jakich sferach dochodzi do takich naruszeń.

Mechanizm egzekwowania poszanowania unijnych wartości powinien dotyczyć przestrzegania zasad demokracji, praworządności i praw człowieka (art. 2, ust. 1 TUE). W art. 2 TUE wartości Unii występują łącznie, co nie wyklucza ich rozdzielnego traktowania, lecz samo ujęcie tych zagadnień w taki sposób sugeruje szeroki zakres zainteresowania Rady, czyli całościowe ujęcie europejskich wartości, które pozostają niepokojąco ogólne.

Zawieszenie niektórych praw państwa członkowskiego, w tym prawa głosu w Radzie, jest nie tylko negatywnym skutkiem prawnym (art. 7, ust. 3 TUE), wynikającym z naruszenia pierwszych zasad UE, lecz również sposobem prewencyjnej izolacji pozostałych państw Unii od państwa dopuszczającego się pogwałcenia tych zasad; jest swego rodzaju nałożeniem moralnej kwarantanny, co powinno zniechęcić inne państwa członkowskie do dopuszczania się podobnych naruszeń [Müller 2013b, s. 7]. Brak odpowiedniej reakcji na nieprzestrzeganie unijnego sytemu wartości w konkretnym państwie członkowskim rodzi ryzyko nie tylko pogłębienia się kryzysu w tym państwie, ale również upowszechnienia złych praktyk. 


\section{Nowe ramy UE na rzecz umocnienia praworządności}

W lipcu 2013 r. Parlament UE w tzw. raporcie Tavaresa wezwał do utworzenia systemu wczesnego ostrzegania: „państwa członkowskie poddawano by regularnej ocenie w zakresie trwałego przestrzegania wartości podstawowych Unii oraz wymogów demokracji i praworządności" [Rezolucja... 2013, s. 34]. W odpowiedzi Komisja Europejska przyjęła Nowe ramy UE na rzecz umocnienia praworządności (dalej: Ramy na rzecz praworządności) [Komunikat Komisji do Parlamentu... 2014]. Zostały one wprowadzone w celu realizacji zobowiązania, które spoczywa na Komisji jako podmiocie wnioskującym do Rady UE o „stwierdzenie istnienia wyraźnego ryzyka poważnego naruszenia przez Państwo Członkowskie wartości, o których mowa w artykule 2" (art. 7, ust. 1 TUE) oraz „stwierdzenie poważnego i stałego naruszenia przez to Państwo Członkowskie wartości, o których mowa w artykule 2” (art. 7, ust. 2 TUE). Jak Komisja zastrzegła: „Ramy te zostaną zastosowane w przypadku, gdy organy państwa członkowskiego będą przyjmować środki lub tolerować sytuacje, które mogą mieć systematyczny negatywny wpływ na integralność, stabilność lub prawidłowe działanie instytucji i mechanizmów ochronnych ustanowionych na szczeblu krajowym w celu zapewnienia praworządności” [Komunikat Komisji do Parlamentu... 2014, s. 7].

Ramy na rzecz praworządności są stosowane, gdy Komisja Europejska stwierdzi systemowe zagrożenie dla porządku politycznego, instytucjonalnego lub prawnego państwa członkowskiego, jego struktury konstytucyjnej, trójpodziału władzy, niezależności i bezstronności wymiaru sprawiedliwości lub kontroli sądowej (w tym sądu konstytucyjnego, o ile istnieje). Z założenia Ramy na rzecz praworządności mają przede wszystkim stanowić prewencyjną formułę dialogu Komisji Europejskiej z państwem członkowskim, w którym praworządność jest zagrożona, prowadzonego w celu wskazania właściwych rozwiązań i zapobiegania nasilaniu się systemowego zagrożenia dla praworządności. Podjęcie działań przez Komisję powinno nastąpić po potwierdzeniu, że środki podjęte przez władze krajowe są pozorne, nieadekwatne lub nieskuteczne [Komunikat Komisji do Parlamentu... 2014, s. 7-8]. Czynności Komisji przebiegają w trzech etapach. W pierwszym etapie Komisja przeprowadza analizę sytuacji obejmującą:

- poszukiwanie rozwiązań w drodze dialogu z danym państwem członkowskim,

- formułowanie obiektywnej i dokładnej oceny danej sytuacji z poszanowaniem zasady równego traktowania państw członkowskich,

- wskazanie szybkich i konkretnych działań, które można podjąć w celu wyeliminowania zagrożenia systemowego i uniknięcia stosowania mechanizmów przewidzianych $\mathrm{w}$ art. 7 TUE. 
W drugim etapie Komisja publikuje zalecenie w sprawie praworządności skierowane do danego państwa członkowskiego, jeżeli uzna, że istnieją obiektywne dowody występowania zagrożenia systemowego oraz że organy tego państwa członkowskiego nie podejmują odpowiednich działań, aby temu przeciwdziałać.

W trzecim etapie Komisja monitoruje działania podjęte przez dane państwo członkowskie w odpowiedzi na skierowane do niego zalecenie. Jeżeli w wyznaczonym terminie dane państwo członkowskie nie podejmuje zadowalających działań następczych, Komisja ocenia zasadność wnioskowania o zastosowanie jednego z mechanizmów określonych $\mathrm{w}$ art. 7 TUE, kontynuując dialog z tym państwem.

Etap trzeci prowadzi do złożenia przez Komisję w Radzie UE wniosku o uruchomienie mechanizmu egzekwowania europejskich wartości na podstawie postanowień art. 7 TUE. Fiasko dialogu Komisji Europejskiej z państwem członkowskim i niezrealizowanie przez to państwo zaleceń Komisji nie musi jednak każdorazowo skutkować złożeniem wniosku, złożenie stosownego wniosku jest bowiem fakultatywne.

W listopadzie 2015 r. Komisja Europejska po raz pierwszy odwołała się do Ram na rzecz praworządności w celu sprawdzenia przestrzegania zasad rządów prawa przez państwo członkowskie. Państwem tym była Polska. Rozmowy Komisji z władzami polskimi nie przyniosły rezultatów (pierwszy etap, zainicjowany 13.01.2016 r.), przekazano więc polskim władzom zalecenia dotyczące utrzymania praworządności, w których szczegółowo opisano stosowne działania naprawcze (drugi etap, 27.07.2016 r.) [Zalecenie... 2016]. W odpowiedzi na działania Komisji (przejście do drugiego etapu) strona polska podważyła nie tyle merytoryczną stronę argumentacji, co samą legalność zastosowania Ram na rzecz praworządności jako procedury ustanowionej bez traktatowej podstawy prawnej². Jeśli Ramy na rzecz praworządności uznać za dodatkową procedurę egzekwowania przestrzegania unijnych wartości, stanowisko władz Rzeczypospolitej jest zasadne. Jeśli Ramy są jedynie wewnętrznym dokumentem Komisji, opisującym pragmatykę postępowania poprzedzającego ewentualne złożenie przez tę instytucję odpowiedniego wniosku w Radzie UE - co jest uprawnieniem Komisji, przewidzianym $\mathrm{w}$ art. 7 TUE - to stanowisko strony polskiej jest nieuzasadnione. Rozstrzygnięcie tej kwestii pozostaje w kompetencji Trybunału Sprawiedliwości

${ }^{2}$ Legalność Ram na rzecz praworządności została jednoznacznie zakwestionowana przez Służbę Prawną Rady UE w 24 pkt ekspertyzy [Opinia... 2014, s. 7]: „Traktaty nie przewidują żadnej podstawy prawnej, która uprawniałaby instytucje do stworzenia nowego mechanizmu nadzoru nad poszanowaniem praworządności przez państwa członkowskie, poza tym przewidzianym w art. 7 TUE, ani też do zmiany, modyfikacji czy uzupełnienia procedury określonej w tym artykule. Gdyby Rada podjęła działanie (w odpowiedzi na wniosek Komisji sformułowany z wykorzystaniem procedury Ram na rzecz praworządności - przyp. R.P.), istniałoby ryzyko, że uznano by to za nadużycie przez nią uprawnień, gdyż podjęłaby decyzję bez podstawy prawnej”. 
Unii Europejskiej (TSUE). Jeśli Polska zaskarży postępowanie Komisji w TSUE, otrzymamy wiążącą odpowiedź.

\section{Wątpliwości związane z zastosowaniem art. 7 TUE oraz Nowych ram UE na rzecz umocnienia praworządności}

Zastosowanie mechanizmu nadzoru przestrzegania europejskich wartości na podstawie art. 7 TUE jest swego rodzaju opcją nuklearną, by posłużyć się sformułowaniem J.M. Barrosy [2013], często pojawiającym się w dyskusjach dotyczących art. 7 TUE. Opcja nuklearna jest rozwiązaniem nie tylko ostatecznym, ale i ryzykownym, nie sposób bowiem przewidzieć jej następstw. Dodatkowe trudności dotyczą określenia okoliczności, w których powinno się stosować ten mechanizm. Zdaniem J.W. Müllera [2013a, s. 3-4], wśród pojawiających się w związku z tym zarzutów można wyróżnić cztery grupy zastrzeżeń, związanych z tym, że:

1) Unia nie jest organizacją spełniającą kryteria demokracji przedstawicielskiej, z trójpodziałem władzy właściwym dla demokracji liberalnej, przez co kontrolowanie przez nią przestrzegania reguł demokratycznego państwa prawa przez państwa członkowskie jest przejawem hipokryzji,

2) nie ma jednego europejskiego standardu demokracji liberalnej, przez co brakuje punktu odniesienia dla ocen jakości demokracji w poszczególnych państwach $\mathrm{UE}^{3}$,

3) interwencyjny aspekt kontroli demokratyzmu i praworządności ma charakter paternalistyczny, co samo w sobie jest działaniem nieliberalnym,

4) jedynie małe i względnie słabe państwa UE mierzą się z zarzutami o naruszanie europejskich wartości, co również jest wyrazem hipokryzji ze strony Unii.

W związku z pierwszym zarzutem Müller zauważa, że UE nie została pomyślana jako paneuropejska demokracja, a zasady, na których została wzniesiona, i standardy prawne przez nią formułowane są oparte na suwerennej decyzji państw członkowskich o ustanowieniu i rozwijaniu unijnego systemu politycznego [Müller 2013a, s. 9]. Zarzucanie braku kompetencji do rzeczowej oceny demoliberalnego charakteru działań rządzących przez podmiot, który sam nie wypełnia demoliberalnych standardów, jest bezzasadne. To nie demokratyzm Unii uprawnia ją do działań kontrolnych. Legitymację do tego rodzaju działań Unia znajduje w prawie pierwotnym (art. 7 TUE), na które państwa członkowskie wyraziły zgodę.

Komentarze dotyczące drugiego zarzutu są jednocześnie najciekawszym wątkiem refleksji Müllera nad rozwojem liberalnej demokracji europejskiej od zakończenia II wojny światowej. O specyfice tego ustroju politycznego, który

${ }^{3}$ Zob. [Witte de i Toggenburg 2004, 17-18]. 
nazywa ograniczoną demokracją (constraint democracy), decyduje delegowanie organom, których członkowie nie są wybierani w wyborach, kontrolowania działań demokratycznie wybranych organów przedstawicielskich tworzących prawo zgodne z wolą większości deputowanych (czyli reprezentantów demos) [Müller 2013a, s. 10]. O jakości demokracji liberalnej decyduje więc kondycja sądownictwa konstytucyjnego, weryfikującego konstytucyjność stanowionego prawa. Losy demokracji europejskich w dwudziestoleciu międzywojennym wzmogły sceptycyzm wobec słuszności idei suwerenności ludu (popular sovereignty) - lud doprowadził do upadku rządów ludowych (demokracji przedstawicielskiej), rezygnując z wolności na rzecz dyktatury. Demokracja, rozumiana jako zespół instytucji politycznych i prawnych demoliberalnego konstytucjonalizmu, nie była w stanie obronić się przed antyliberalną władzą pochodzącą z wyborów.

Koncepcja ograniczonej demokracji, zdaniem Müllera, jest bliższa współczesnemu wyobrażeniu o dobrze działającej demokracji niż demokracja suwerenności ludowej (lub suwerenności parlamentarnej). Powojenne odrodzenie się demokracji europejskiej nadało nową formę rządom ludowym, zostały ustanowione mechanizmy mające zabezpieczyć Europejczyków przed pułapką vox populi, vox Dei. Wola ludu winna podlegać kurateli organu niezabiegającego o wyborczą legitymację, czyli niezależnego. Parlament, będąc reprezentantem ludu, potrzebuje kuratora, którym jest sądownictwo konstytucyjne. W ten sposób Müller przeciwstawia demokratyczny populizm demokratycznemu konstytucjonalizmowi, ograniczającemu rządy większości z wykorzystaniem mechanizmu kontroli sądowej.

Również proces integracji europejskiej w ramach UE ma swój udział w ograniczaniu suwerenności demos w państwach członkowskich (choć nie został jako taki pomyślany, to w rezultacie można go za taki uznać). Prawo unijne jest ponadnarodowym ograniczeniem suwerenności parlamentarnej [Müller 2014, s. 147].

W odpowiedzi na trzeci zarzut, kwestionujący liberalny charakter paternalistycznego recenzowania przez UE kondycji demoliberalnego konstytucjonalizmu w państwie członkowskim, którego obywatele (ich większość) nie reagują negatywnie na działania swoich władz, Müller przywołuje dwa kontrargumenty. Po pierwsze, przypomina, że wezwanie do zachowania przez UE neutralności w tej kwestii samo w sobie nie jest neutralne. Po drugie, podkreśla, że zgodnie z unijnym prawem pierwotnym Komisja Europejska oraz TSUE są strażnikami traktatów, jako że nieprzestrzeganie prawa UE przez jedno z państw członkowskich wywołuje negatywne skutki dla pozostałych państw, w których interesie leży podjęcie przez Komisję odpowiednich działań. Jednocześnie, jak zauważa Müller, wyborczy mandat władz krajowych naruszających pierwsze zasady ustrojowe demoliberalnego konstytucjonalizmu nie podważa zasadności interwencji unijnej, naruszenie bowiem podstawowych praw jednego obywatela UE jest przedmiotem zainteresowania Unii jako całości („W interesie każdego obywatela Unii leży brak koniecz- 
ności konfrontowania się z nieliberalnym państwem członkowskim (...) Mogłoby być prawdą, że istnieją dalekie państwa z ludźmi, o których niczego nie wiemy ale jak długo pozostają oni w Unii, tak długo nas interesują" [Müller 2013a, s. 12]). Eksternalizacja wewnętrznych spraw państw członkowskich w ramach UE jest oczywista z uwagi na zaawansowany stopień integracji europejskiej, która wymaga solidarnego uznawania unijnych wartości. Choć Unia ma ograniczoną zdolność upowszechniania swych wartości w otoczeniu zewnętrznym, to zagwarantowanie ich nienaruszalności w obrębie samej Unii pozostaje priorytetem.

Czwarty zarzut dotyczy wybiórczego charakteru interwencjonizmu Unii. Jedynie małym lub relatywnie słabszym państwom przychodziło zmierzyć się z krytyką dotyczącą nieprzestrzegania zasad i z działaniami egzekwującymi ich przestrzeganie. Gdy w Austrii zawiązano koalicję rządową z Partią Wolności J. Haidera, słowa krytyki i wezwania do poczynienia zdecydowanych kroków płynęły zarówno z Paryża, jak i Berlina, choć J. Chirac nie potrafił efektywnie przeciwdziałać rozwojowi Frontu Narodowego J.M. le Pena, a G. Schröder neonazistowskiej NPD [Müller 2013a, s. 12]. Niezdolność do przeprowadzenia konstruktywnych działań we własnych krajach wzmacniała gotowość do formułowania negatywnych ocen rozwoju wydarzeń w Austrii. Przeciw temu zarzutowi Müller nie występuje $\mathrm{z}$ wartościowym kontrargumentem.

Uwagi Müllera są ogólne, dotyczą kompetencji Unii jako takiej, dążącej do poszanowania swych wartości, opisanych $w$ art. 2 TUE, lecz można je z powodzeniem odnieść do postępowania Komisji z wykorzystaniem Ram na rzecz praworządności. Inni autorzy poddają krytycznej ocenie samo przyjęcie Ram na rzecz praworządności. Ich obserwacje są na tyle istotne, że należy je tu przywołać.

Po pierwsze, działania monitorujące są podejmowane przez Komisję w efekcie jej własnej oceny zagrożenia praworządności w konkretnym państwie UE. Nie jest to więc stała porównawcza i okresowa ewaluacja kondycji praworządności we wszystkich państwach członkowskich. W konsekwencji każde państwo, wobec którego zostaną zastosowane Ramy na rzecz praworządności, może niebezpodstawnie twierdzić, że stało się ofiarą wybiórczych (arbitralnych) działań, przekonując, że problemy z praworządnością w innych państwach nie są przedmiotem zainteresowania Komisji.

Po drugie, Komisja deklaruje w swym komunikacie, że podejmując się samodzielnej oceny kondycji praworządności w państwie członkowskim, będzie się posiłkować opiniami ekspertów zewnętrznych, Agencji Praw Podstawowych Unii Europejskiej, sieciami sądowymi UE ${ }^{4}$ oraz Komisji Weneckiej [Komunikat Komisji do Parlamentu... 2014, s. 10]. W Ramach na rzecz praworządności nie

${ }^{4}$ Do sieci sądowych UE należą: Sieć Prezesów Sądów Najwyższych Unii Europejskiej, Stowarzyszenie Rad Stanu i Naczelnych Sądów Administracyjnych Unii Europejskiej, Europejska Sieć Rad Sądownictwa. 
opisano żadnego mechanizmu kontroli działań Komisji przez Parlament Europejski czy TSUE.

Po trzecie, Ramy na rzecz praworządności podważają skuteczność art. 7 TUE, arbitralność postępowania Komisji może bowiem sprzyjać poszukiwaniom sojuszników przez państwo, wobec którego je zastosowano. W efekcie kraje, które potencjalnie mogłyby znaleźć się w kręgu zainteresowania Komisji, skutecznie blokują postępowanie w Radzie UE przeciwko państwu, wobec którego Komisja zastosowała Ramy na rzecz praworządności.

Po czwarte, w Ramach na rzecz praworządności nie przewidziano precyzyjnej metodologii badań z wykorzystaniem modelu porównawczego ani szczegółowej strategii pozwalającej na koordynację działań Unii w odpowiedzi na wyniki postępowania monitorującego Komisji w kolejno poddawanych ocenie państwach członkowskich [Bárd i in. 2016, s. 40]. Komisja nie zdefiniowała również kluczowego pojęcia wykorzystanego w Ramach na rzecz praworządności, a mianowicie systemowego zagrożenia dla zasad praworządności, w odróżnieniu od systemowego pogwałcenia tych zasad [Kochenov i Pech 2015, s. 12].

\section{Materia unijnych wartości}

Trzeci zarzut określony przez Müllera jest na tyle istotny, że warto go dokładniej przeanalizować. Dotyczy treści, którą rozumie się pod pojęciami demokracji, rządów prawa i praw człowieka. Samo umieszenie ich w katalogu wartości powszechnie uznawanych w państwach członkowskich Unii nie budzi wątpliwości, lecz z ustaleniem znaczeń nadawanych pojęciu rządów ludowych, praworządności oraz praw człowieka wiążą się już pewne kontrowersje.

Co symptomatyczne, współcześnie zwykło się traktować te obiekty jako współzależne, przez co podczas prób definiowania demokracji sięga się po pojęcia praworządności i praw człowieka. Praworządność jest umieszczana w kontekście demokratycznego ustroju politycznego, z właściwymi gwarancjami praw podstawowych, najlepsze otoczenie dla praw człowieka ma zaś stanowić demokratyczne państwo prawa. Demokracja, prawa człowieka oraz praworządność można więc przedstawić na schemacie trójkąta obrazującym unijny system wartości, konstrukcję z wzajemnie powiązanych i współzależnych elementów [Carrera, Guild i Hernanz 2013]. Jak zauważyła Komisja Europejska [Komunikat Komisji do Parlamentu... 2014, s. 4-5]:

(...) poszanowanie praworządności jest nierozerwalnie powiązane z poszanowaniem zasad demokracji i praw podstawowych: nie może być demokracji i poszanowania praw podstawowych bez poszanowania praworządności i odwrotnie. Prawa podstawowe są skuteczne tylko wtedy, gdy mogą być dochodzone na drodze sądowej. Demokracja jest 
chroniona, jeśli zasadnicza rola sądownictwa, w tym trybunałów konstytucyjnych, może zapewnić wolność wypowiedzi, wolność zgromadzeń oraz poszanowanie zasad regulujących proces polityczny i wyborczy.

Współzależność wartości europejskich nie uwalnia jednak od dylematów związanych z ustaleniem treści kryjących się za tymi wartościami, a być może nawet potęguje wątpliwości. Zdaniem Müllera, właściwe funkcjonowanie demokracji przedstawicielskiej wymaga ograniczenia suwerenności ludowej, ani prawa człowieka, ani praworządność nie będą bowiem zagwarantowane bez kurateli ze strony niepochodzącego z wyborów organu wyposażonego w prerogatywę kontroli konstytucyjności prawa stanowionego przez przedstawicieli ludu. Efektywność sądowej kontroli konstytucyjności (judicial review) jest warunkiem praworządności, a pośrednio również stabilności rządów ludowych. To nie powszechność praw wyborczych, regularnie przeprowadzane wybory, w wyniku których uzyskuje się mandat, decyduje o demokratyzmie systemu politycznego, lecz skuteczność powściągania woli większości przez niepochodzące z wyborów sądownictwo konstytucyjne, podejmujące działania w sytuacji, gdy uzna, że wola większości narusza prawa mniejszości.

Można przyjąć, że na charakterystykę liberalnej demokracji składają się następujące elementy: 1) idea rządu reprezentatywnego, 2) zasada uzależnienia prawomocności władzy publicznej od zgody rządzonych (popular consent), głównie poprzez wybory powszechne, odbywające się wystarczająco często, by uwzględnić przesunięcia w zakresie politycznych preferencji rządzonych,3) możliwie szeroka dostępność prawa wyłaniania rządzących, czyli prawa zabezpieczającego efektywną przynależność do demos, 4) konieczność poszukiwania przez rządzących publicznego, rozumnego uzasadnienia swych decyzji, 5) zasada trójpodziału władzy, by w imię zabezpieczenia wolności rządzonych władza powściągała władzę, 6) konstytucyjne gwarancje wolności jednostki, ograniczające władzę, zarówno co do jej przedmiotu, jak i sposobu jej egzekucji, a także eliminujące zagrożenie wykorzystania aparatu państwowego przez większość przeciwko mniejszości. Elementy te nie tworzą struktury hierarchicznej, w której jeden element warunkuje następny. W rozważaniach Müllera można jednak dostrzec przedkładanie 4, 5 i 6 nad 1, 2 i 3. Müller przedkłada efektywną ocenę konstytucyjności stanowionego prawa w procesie kontroli sądowej nad możliwość realizacji woli większości wyrażonej w procesie wyborczym. Jest to ruch w kierunku uznania supremacji judykatywy względem pozostałych dwóch gałęzi władzy.

Choć historia współczesnej Europy pozwala uzasadnić sposób rozumowania Müllera, to jego poprawność budzi wątpliwości. Rozważania możliwości osignięcia ideału systemu checks and balances znajdują się w centrum dyskusji nad praktyką ustrojową liberalnych demokracji, zwłaszcza w świecie anglosaskim. Można się jednak zastanawiać, czy kuratela sądownictwa konstytucyjnego jest 
mechanizmem równoważenia władz, czy może jest dowodem przesunięcia punktu ciężkości w zakresie sprawowania władzy publicznej w kierunku judykatywy. Jeśli bowiem nieodpowiadający przed demos organ jest władny sprzeciwić się woli większości w ciele przedstawicielskim ludu, to zasadne jest pytanie o osobę suwerena. Jak sugestywnie przekonuje R.A. Dahl [1995, s. 77-116], kuratela nie jest mechanizmem ochrony rządów ludowych, lecz jest ich przeciwieństwem. Napięcia pomiędzy legislaturą i sądem konstytucyjnym są nieuchronne, a wystąpienie konfliktu wysoce prawdopodobne, co potwierdzają doświadczenia węgierskie sprzed kilku lat oraz aktualny rozwój wydarzeń w Polsce.

Należy także podkreślić, że fenomen praworządności w realiach demokratycznego reżimu politycznego jest na tyle złożony i przedmiotowo nieoznaczony, że brak jego unijnego wzorca, będącego efektem zgodnej konceptualizacji i efektywnej operacjonalizacji, nie jest zaskoczeniem. Anglosaskie rule of law, niemieckie Rechtsstaat czy francuskie état de droit nie są konstrukcjami w pełni przystawalnymi. Praworządność rozwijana w różnych kulturach prawnych zachodniego świata jest w oczywisty sposób skazana na partykularyzm znaczeniowy. Trudność ta nie wyklucza możliwości podejmowania starań wypracowania uniwersalnego ujęcia praworządności, jej standardu. Zadania tego rodzaju podjęła się Europejska Komisja na rzecz Demokracji przez Prawo (Komisja Wenecka), działająca w ramach Rady Europy. Ustalenia Komisji Weneckiej dotyczące rozumienia praworządności mają charakter pragmatyczny: wynikają z doświadczeń zdobytych podczas postępowań monitorujących podejmowanych przez zespoły robocze sprawdzające stan praworządności w poszczególnych państwach Rady Europy. Komisja Wenecka przyjmuje następujące rozumienie rządów prawa [Report... 2011, s. 5]:

Rządy prawa, właściwie rozumiane, są nieodłącznym elementem każdego demokratycznego społeczeństwa, a koncepcja rządów prawa wymaga, by każdy był traktowany przez decydentów z godnością, równością, racjonalnie i w zgodzie z prawem; by każdy miał możliwość zaskarżenia bezprawnych decyzji przed niezależnymi i bezstronnymi sądami, które działają w oparciu o sprawiedliwe procedury. Rządy prawa odnoszą się więc do władzy i relacji między jednostką i państwem.

Komisja Europejska, opierając się na ustaleniach Komisji Weneckiej, tradycji ustrojowej państw członkowskich oraz orzecznictwie TSUE, przyjmuje, że na rządy prawa składają się następujące elementy: legalność (przejrzysty, odpowiedzialny, demokratyczny i pluralistyczny proces uchwalania prawa), pewność prawa, zakaz arbitralności w działaniu władz wykonawczych, niezależne i bezstronne sądy, skuteczna kontrola sądowa, w tym kontrola poszanowania praw podstawowych, oraz równość wobec prawa. Niemniej jednak opis praworządności przygotowany przez Komisję Europejską ma charakter poglądowy, nie jest to zbiór precyzyjnych zasad, nie określono również instrumentarium weryfikacji rządów 
prawa w poszczególnych państwach członkowskich. Innymi słowy, ogólność sformułowań Komisji Europejskiej podważa operacyjną zdolność oceniania stopnia spełnienia przez państwa członkowskie kryterium praworządności.

Wątpliwe jest również to, czy wypełnianie „unijną” treścią pojęcia praworządności pozwoli na uniknięcie kontrowersji związanych z praktyczną realizacją podstawowych zadań rządów prawa [Bárd i in. 2016, s. 53]:

(...) koniecznie musimy sobie zdać sprawę z tego, że samo zdefiniowanie rządów prawa w najlepszy możliwy sposób nie może uwolnić nas od ich natury, czyli od tego, że są one w gruncie rzeczy kontestowaną koncepcją. Ważne, by pamiętać, że nawet najdokładniejsze definicje, oddające ideę rządów prawa, muszą zawierać pewną nieokreśloność, aby uwzględnić samą naturę rządów prawa. Ten wymóg nieokreśloności odgrywa ważną rolę we wszelkich próbach donkiszoterii dążącej do zamiany rządów prawa w pozycje na jakiejś liście zakupowej, nawet jeśli znamy całkiem dobre listy tego rodzaju. Całkowita eliminacja nieokreśloności zupełnie podważa użyteczność koncepcji rządów prawa jako taką.

Unia Europejska wypracowała mechanizmy (procedury) poszanowania unijnych wartości przez państwa członkowskie, lecz nie zadbano o ich wystarczająco przejrzysty wymiar materialny. Mechanizmowi egzekucyjnemu opisanemu w art. 7 TUE oraz Ramom na rzecz praworządności przygotowanym przez Komisę Europejską zarzuca się uznaniowość dotyczącą ich stosowania, co może prowadzić do przekraczania uprawnień przez Komisję lub całą Unię. Jeśli nie można spodziewać się satysfakcjonującej operacjonalizacji unijnego rozumienia praworządności (wypełnienia jej treścią), może się okazać, że ustanowione mechanizmy monitorowania i egzekwowania unijnych wartości pozostaną bezużyteczne [Bárd i in. 2016, s. 63-64].

\section{Podsumowanie}

Związek pomiędzy możliwościami trwania i rozwoju unijnego projektu integracji europejskiej a podzielaniem przez uczestniczące w nim państwa wspólnych wartości jest oczywisty. W żywotnym interesie UE leży nienaruszalność wartości (pierwszych zasad), na których opiera się wspólnota gospodarcza, polityczna i społeczna państw oraz społeczeństw. Nieuniknione różnice interesów dają się zrównoważyć przez powszechną zgodę dotyczącą wspólnych wartości. Niezbędne jest więc efektywne egzekwowanie poszanowania tych wartości.

Krytyczna ocena mechanizmów egzekwowania poszanowania unijnej aksjologii, wyłożonej w art. 2 TUE, wypada negatywnie. Zastosowanie art. 7 jest opcją nuklearną, a nie opracowano konwencjonalnej alternatywy. Ramy na rzecz praworządności, przygotowane przez Komisję Europejską, miały stać się takim 
narzędziem, lecz z ich ustanowieniem wiążą się wątpliwości traktatowe, na co zwróciła uwagę Służba Prawna Rady UE. Nie opisano w nich mechanizmu stałego monitoringu przestrzegania unijnych wartości przez wszystkie państwa członkowskie. Przeszkodą w ich efektywnym wykorzystaniu jest swoista, naturalna nieokreśloność koncepcji rządów prawa, praw człowieka, ale i demoliberalizmu. Wypracowanie obiektywnego narzędzia pomiarowego pozwalającego na porównanie kondycji wartości wskazanych w art. 2 TUE we wszystkich państwach członkowskich jest potrzebne, realizacja tego zadania jest jednak mało prawdopodobna ze względu na skalę związanych z tym trudności. Owa nieokreśloność nie jest przeszkodą $w$ formułowaniu ocen politycznych, lecz jest niemożliwa do zaakceptowania $\mathrm{w}$ wypadku ocen prawnych. Jeśli polityczne oceny leżą w gestii ewidentnie politycznego organu w systemie instytucjonalnym UE, czyli Rady, to należy wrócić do art. 7 TUE, czyli do opcji nuklearnej - punktu wyjścia przedstawionych rozważań.

Na podstawie zaprezentowanych analiz można sformułować pewną obserwację: w środowisku międzynarodowym państwa angażują się wolicjonalnie w różnorodne formy współpracy, w tym w projekty integracyjne. Dążenie do współpracy jest równie silne jak egoizm narodowy; samoograniczenie, będące warunkiem zgodnej kooperacji, jest skutecznie równoważone przez żądanie poszanowania prawa do suwerennego stanowienia o sobie. W UE wzrasta obawa o stabilność reguł liberalnej demokracji, dotyczy to co najmniej kilku państw członkowskich. Nie należy ignorować tego problemu. Pozostaje jedynie mieć nadzieję, że niewątpliwe zalety liberalnego konstytucjonalizmu - liberalnej demokracji, praworządności i praw człowieka - wciąż będą wystarczająco wyraźnie dostrzegane przez społeczeństwa krajów będących uczestnikami unijnego projektu politycznego. O wyborze tego konstytucjonalizmu nie powinna jednak decydować obawa przed możliwą sankcją, lecz nadzieja na pokój i dobrobyt.

\section{Literatura}

Bárd P., Carrera S., Guild E., Kochenov D. [2016], An EU Mechanism on Democracy, the Rule of Law and Fundamental Rights, „CEPS Paper in Liberty and Security in Europe", nr 91.

Barroso J.M. [2013], Orędzie o stanie Unii Europejskiej w 2013 roku, Sesja plenarna Parlamentu Europejskiego w Strasburgu, 11 września 2013 r., http://europa.eu/rapid/ press-release_SPEECH-13-684_pl.htm (data dostępu: 10.01.2017).

Bugarič B. [2014], Protecting Democracy and the Rule of Law in the European Union: The Hungarian Challenge, ,LEQS Paper”, nr 79, https://doi.org/10.2139/ssrn.2466340. Búrca G. de [2004], Beyond the Charter: How Enlargement Has Enlarged the Human Rights Policy of the European Union, „Fordham International Law Journal”, vol. 27. 
Búrca G. de [2013], Europe's raison d'être [w:] European Union's Shaping of the International Legal Order, red. D. Kochenov, F. Amtenbrink, Cambridge University Press, Cambridge.

Carrera S., Guild E., Hernanz N. [2013], The Triangular Relationship between Fundamental Rights, Democracy and Rule of Law in the EU: Towards an EU Copenhagen Mechanism, „CEPS Paperbacks”, 20 November.

Dahl R.A. [1995], Demokracja i jej krytycy, Znak, Kraków.

Kochenov D., Pech L. [2015], Upholding the Rule of Law in the EU: On the Commission's 'Pre-Article 7 Procedure' as a Timid Step in the Right Direction, EUI Working Papers, RSCAS 2015/24, Badia Fiesolana, https://doi.org/10.2139/ssrn.2625602.

Müller J.W. [2013a], Safeguarding Democracy inside the EU: Brussels and the Future of Liberal Order, Transatlantic Academy Paper Series, nr 3.

Müller J.W. [2013b], Should the EU Protect Democracy and the Rule of Law inside Member States?, https://www.princeton.edu/ jmueller/ELJ-Democracy\%20Protection-JWMueller-pdf.pdf (data dostępu: 20.09.2016).

Müller J.W. [2014], The EU as a Militant Democracy, or: Are There Limits to Constitutional Mutations within EU Member States?, „Revista de Estudios Políticos”, nr 165.

Sadurski W. [2010], Adding Bite to a Bark: The Story of Article 7, E.U. Enlargement, and Jörg Haider, „Columbia Journal of European Law”, vol. 16, nr 3.

Witte B. de, Toggenburg G. [2004], Human Rights and Membership of the European Union [w:] The EU Charter of Fundamental Rights, red. S. Peers, A. Ward, Hart Publishing, Oxford.

\section{Dokumenty Unii Europejskiej i Rady Europy}

Komunikat Komisji do Parlamentu Europejskiego i Rady: Nowe ramy UE na rzecz umocnienia praworządności [2014], COM(2014) 158 final, Strasburg.

Komunikat Komisji do Rady Europejskiej i Parlamentu Europejskiego dotyczący art. 7 Traktatu o Unii Europejskiej: Poszanowanie i promocja wartości, na których opiera się Unia [2003], COM(2003) 606 final, Bruksela.

Opinia Służby Prawnej Rady Unii Europejskiej dotycząca Komunikatu Komisji w sprawie nowych ram UE na rzecz umocnienia praworządności - zgodność z Traktatami [2014], 10296/14, Bruksela, http://data.consilium.europa.eu/doc/document/ST-10296-2014INIT/en/pdf (data dostępu: 20.09.2016).

Report on the Rule of Law, Adopted by the Venice Commission at Its 86th Plenary Session (Venice, 25-26 March 2011) [2011], CDL-AD(2011)003rev, Strasburg, http://www. venice.coe.int/webforms/documents/?pdf=CDL-AD(2011)003rev-e (data dostępu: 20.09.2016).

Rezolucja Parlamentu Europejskiego z dnia 3 lipca 2013 r. w sprawie sytuacji praw podstawowych: standardy i praktyki na Węgrzech (zgodnie z rezolucją Parlamentu Europejskiego z dnia 16 lutego 2012 r.) [2013], P7_TA(2013)0315, Strasburg, http:// www.europarl.europa.eu/sides/getDoc.do?pubRef=-//EP//NONSGML+TA+P7-TA-2013-0315+0+DOC+PDF+V0//PL (data dostępu: 20.09.2016).

Zalecenie Komisji z dnia 27.07.2016 r. w sprawie praworządności w Polsce [2016], $\operatorname{COM}(2016) 5703$ final, Bruksela. 


\section{The Inviolability of the European Union's Values - a Critical Analysis of TEU's Article 2 Execution Mechanism}

(Abstract)

The inviolability of the European Union's values is of vital interest to the Union. The list of these values is laid down in article 2 of TEU, while Article 7 lays down the mechanism of their enforcement. The terms and conditions for using Article 7, and anxieties about possible outcomes, have led this article to be dubbed the nuclear option. Its nature prompted the European Commission (EC) to adopt a more practical tool the New Framework to Strengthen the Rule of Law (2014). Responding to the prolonged constitutional crisis in Poland, the EC has now for the first time invoked its framework to evaluate the conditions of rule of law in a particular Member State.

This article presents a critical analysis of the mechanism enabled by Article 7 and the tool created by the EC. The analysis proves that Union's instruments established to enforce respect for its values are ineffective, which limits its ability to properly respond to the violation of these values and effectively secure the vital interests of the European Union as well.

Keywords: European Union' values, article 7 of the TEU, the EU framework to strengthen the rule of law, J. W. Müller. 